\title{
STUDIES ON CILIATED EPITHELIUM OF NASAL CAVITIES AND PARANASAL SINUSES
}

Part II. Allergic Phenomenon of the Ciliated Epithelium

By

R. MATSUMOTO

From the Department of Oto-Rhino-Laryngology, Tokushima University School of Medicine (Director: Prof. G. Shirakawa)

Ciliatedepithelial cells of man and rabbits wer studied under a phase contrast microscope, praducing allergic reaction in the cells. The findings were as follows:

1) Non-sensitized human ciliated epithelial tissue was destroyed by the the addition of $1: 10$ or stronger histamine solution. With weaker solution than 1: 10, increased ciliary activity was noted. By the stimulation with 1:2000 or stronger solution, sensitized epithelial tissue schowed shirinkage of the epithelial cells, increase of activity, cessation of activity, or destruction of cilia and cells. By the addition of 1: 1000 or stronger acetylcholine solution, non-sensitized epithelial tissue was destroyed by 1: 1000 or stronger solution, whereas sensitized epithelial tissue was destroyed by 1: 5000 or stronger solution. Tissue reaction to histamine and acetylcholine was closely resemble to allergic reaction, suggesting the production of these toxic substances in allergic reaction.

2) The antigens were added to sensitive human ciliated epithelial tissue from the sinues. Shrinkage of the cells, temporal increase of activity, enlargement of granules in cytoplasm, destruction of cilia, swelling of the cells and destruction of the cells. Similar changes were also observed when the antigen was added to the sinus mucosa of rabbit sensitized by egg-white albumin.

3) When the antigen was introduced into the paransal sinuses of sensitized rabbits, moderate decrease and weakening in the ciliary activity, shrinkage of the cells, and loss of cilia, were observed but not the remarkable allergic reactions observed under the microscope. This suggests that such a drastic allergic reaction seen in vitro does not take place in vivo.

4) Intra-arterial injection of the antigen to the sensitized rabbits showed cessation of the ciliary activity, falling off of the cilia and atrophy of the cells. It can be presumed that such phenomena may develop also in man with food allergy, playing a significant role in the development of sinusitis.

5) In a state of vagotony, the ciliary activity was moderately decreased and weakened, but when adrenalin was added, the activity returned to healthy condition. When the allergen was again added, allergic reaction occurred more rapidly and intensely than in normal rabbits which had been sensitized.

6) The ciliary activity in adrenalectomized animals was moderately decreased and weakened, with an about 20 percent loss of cilia and atrophy of the cells. The ciliary movement returned to normal when Interenin was given. The ciliary activity was more depressed and the loss of cilia was more remarkable in animals sensitized after adrenalectomy. When the allergen was given, marked allergic reaction developed in brief periods of timé. 
7) In thyroidectomized animals, the ciliary activity was midly depressed, exhibited mild but neither the loss of cilia nor the shrinkage of the cells was noted. When the Thyracin was added, the ciliary activity returned to normal. In sensitized animals, also the ciliary activity showed mild depression and when the allergen was added, allergic reaction was developed. However the reaction in this instance was generally milder than that seen in adrenalectomized animals.

8) When the epithelium of the sinus mucous membrane in the cases with positive reaction to bacterial precipitation test was subjected to the action of the bacterial suspension of the same kind, allergic reaction developed likewise in the ciliary cells. The reaction continued longer and was weaker than that caused by other antigens.

When the bacterial suspension was added to the sinus mucosa of the animals which showed positive precipitation test for the bacteria, allergic reaction was abserved in the ciliated epithelial cells. The reaction was milder and the duration of the reaction was longer, compared with thereaction to other antigens.

\section{鼻腔及副鼻腔線毛上皮に関する研究}

第 2 編 線毛上皮のアレルギー現象

德島大学医学部耳悬咽屁科教空（主任：白川教授）

松本甞治

\section{I 緒 言}

上気道に和ける疾患をアレルギー的立場より観察さ れ始めたのは比較的新しく且つ歴史も浅い。1900年 Fraenkel は気管支喘息によつて死亡した患者の死体解 剖より気管粘膜に病的変性をきたしていると注目すべき 発表を行つた. 1922 年頃 Huber u. Koessler は気管 支喘息に権患すると気管の粘膜上皮に形態学的変化をき たすことを発表した・このことは1938 年臨林病理学会 に和いて確認され，よ弓やくアレルギ一性上気道疾患 に括恬る線毛上皮細胞の形態学的变性が学者の注目を浴 るようになつた・1943年 Hilding は感作家臣の悬孔を 閒塞し，これに急性のアレルギー性変化を起さしめ, そ のアレルギー状態下に打ける線毛運動钼察した・さら に Ballenger は実験的に動物の線毛上皮に antigen を作用させてその線毛運動を観察し，又人間に allergen を作用させ acute allergic attackを生ぜしめた所， 明らかに線毛運動機能に変化を認めたと述べている・こ のことより1949年 Rose は害鵌的に証明せんとして， 線毛の遊離細胞を allergen を添加せる培養液で組維培
盖を行い、これに更に allergen を滴下して顕微鏡下に 線毛細胞のアレルギー反応を証明した・斯くの如く上気 道の線毛上皮細胞に関する研究は外国にはあるが本邦に。 おいてはこの種の研究は全くなされて抢らず，わすが 武田が単細胞に叔けるアレルギー反応の研究を行ってい るのみに過ぎない, 私は今回, 慢性副鼻腔炎をアレルギ 一的立場から観察する教室一連の研究の一端として, 人 副鼻腔粘膜に和ける線毛上皮細胞のア、レルギー反応を， 更に家臣に和いて種々の条件下に物ける緑毛上皮細胞の アレルギー反応を位相差䫓锺鏡下に観察し，これを映画， に記録することに成功したので妶にその要旨を発表する。 次第である.

\section{II 実験及び観察方法}

慢性副毁腔炎患者火卵白，魚，牛乳，野菜，牛肉の 5 . 種の抽出液と，3 種の細菌の自家ワクチンにより皮内反 応を施行し，その皮内反応陽性物に対し，さらに沈降反 応を検し，その液を陽性に出現した人の上顠洞より手街 によつて剔出，封入した遊離線毛緇胞に滴下した(正常細 胞においてなんら变化を認めざる最高稀釈度 $0.2 \%$ 液多 


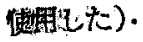

双成率白色家鬼感作を施し Arthus 反灾を検し， しかる後にこれ種々の条件を附加して，副悬腔安開放 して粘膜を剔出，生理的食塩水あるいは $0.2 \%$ 葡萄糖加 ワンゲル氏液中に封入し，薬物刺㦸，あるいはマレルゲ ン刺战を加吝た・斯くしたものを $37^{\circ} \mathrm{C}$ 保温の下に位相 美㩆微鏡下に観察し，文映画撮影装置を附属せしめて随 处を撮影記録した。

\section{III 線毛上皮に対する薬物刺戟}

アレルギー反応に和ける七スタミン及びアセチールコ ウン学説よりこの両者が線毛運動に対する影響を考光， この象騃を行つた・

1)人線毛細胞に対するヒスダン刺㦸

10 倍より 10,000 倍侄る種々の濃度のヒスタ、ン液 る作り生理的食塩水飞封入し，活湑なる線毛運動を有す る細胞を非アンルギー性とアレルギ一性とに別ち，爷れ それ作用せしめた。非アンルギー性炕あつては10倍 の高浧度ヒスタミン液に执いては，数分内に急激に線毛 運動索停止し細胞体の透明度は高方，細胞体の崩壞現 象を発現した。而しながらそれ以上つ 1,000 倍〜10,000 倍侄る稀积度の薄いるのにおいては線毛細胞つ細胞体 は軽度に收縮するも，線毛運動は停止することなく却つ て運動は兄進する。これを1,000 倍つとスタミン液作用

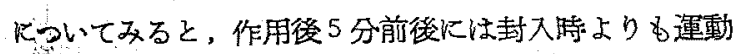
は焳するが，10 分後见は急激に運動の減退を呈する， その後は漸次堿退を示し，30 分後に沶いてはその運動 頻度は封入時の約半数となる・しかし運動はこのまつ1

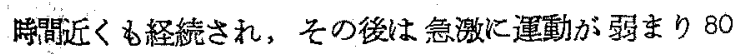
分後には停止した・アレルギー性にあっては 5,000 倍以 上の稀释度において，細胞は軽度に収縓現象を呈し線毛 連動は六進するが，これ以下゙の高濃度に执いて，特に 2000倍を中心としたるのでは，作用直後線毛運動は一 時䄪に九進した後, 急激に弱り細胞体の著しい収縮と共

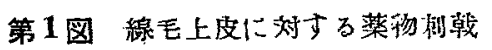
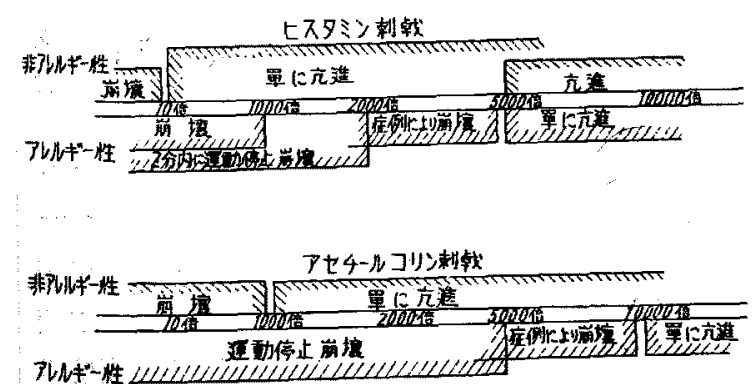

に線毛運動は完全に停止する・しかる後小皮緑下の顆粒 は增加し，次いで線毛の配列は乱れ遂次脱落を始め，時 間的経過と共沉細胞体は崩壊現象を呈する・而しながら 症例によつては 5,000 倍でる崩壊現象を呈するものむあ り，又1,000 倍儿和いて始めて崩壊現象を呈するすのる あつた・斯くの如き相異は身体内で起つたアレルギー反 応によつて産出されたとスタミンを細胞が含有する量の 多察によるるのと推測される・この現象はヒスタミンの 濃度が婊い程早く発現するが，概してアレルギー性の方 が非アレルギー性よりも低濃度に上く反応する。

2) 人楾毛細胞に対するアセチールニリン刺㦸 前記同様 10 倍より 10,000 倍に至る稀釈液を作り，こ れをアレルギー性のものと非アレルギー性のすのとに作 用させた・非アレルギー性及びアレルギー性の゙ずれに あつてる10,000 倍の稀积度に和いては、アせチールン リン刺战後直ちに線毛運動小儿進状態を示し，5分後運 動は急激に促進し始め，乙の細胞の舆鹪状態は20 分值 が最大であつて，線毛運動は激烈を極め，頻度は1分間 550 回以上を算えた・而しながらこの與睢状態る30 分

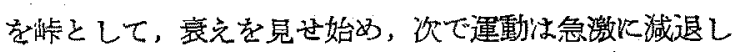

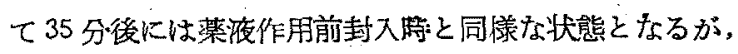
60 分後においては運動は完全に停止する.細胞体は非 常に澄明となるが長特間を経ても膨化現象は呈しなかつ た・同様な現象仙非アレルギー性炕括いては 1,000 倍〜 10,000 倍の稀释度の間でる起つたが，アレルギー性にあ つては5,000 倍以上で起つた. 非アレルギー性に蛒いて は 1,000 倍以下゙の高濃度つア゙チールンリン刺战に対し ては作用と同時汇線毛運動は激烈ととなるも瞬時沉して 停止し，直ちに細胞体は澄明となり細胞膜は破九顆粒は 流出し線毛は飛散し 30 秒以内に細胞は崩壊現象を呈し, その原型を止めない。アレルギー㤬のるのでは 5,000 倍 以下の液にて同様な現象が起つた。

第 2 図 線毛運缍に対与る薬物制戟

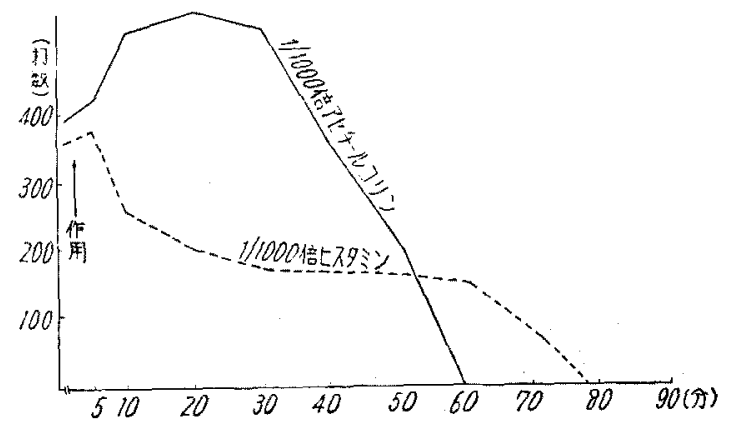


3) 人副鼻腔楾毛上皮のアレルギー現象

慢性副宜腔炎患者に我々が日常最むよく摄取する食物 である牛乳，卵白，牛肉，魚肉，野菜等の抽出液で皮内 反応を試み，その陽性物質を食物として特別食を与え白 血球減少指数を湘定し，更に沈降反忘を試み，これ等の 陽性物質中最す鋭敏なるものを選定後, これ等の抽出液 の $0.2 \%$ 稀釈度液を，葡萄糖加リンダル氏液中に封入せる 逝離線毛細胞に還流せしめながら作用させた・細胞にフ レルゲンが達すると細胞体は軽度に収縮しながら線毛運 動は一㭙的に與奮状態に楩り，数分後に線毛運動は完全 に停止する、暫㭙にして細胞原形質は澄明となり，原形 質流動も又停止するに及んで，細胞内顆粒は大さくなり その数を増すが，この間にあつて線毛の形，排列は乱れ 一部小皮縁より脱落現象を呈するようになる・次いで細 胞内には水泡の形成が起り，この水胞は次ょと核区び小 皮縁を圧迫するに至れば，線毛は芜㳄脱落分離し，細胞 体は大きく膨み原型の2 倍弱となり膨化現象を呈してく るようになる・このようになれば細胞体の光の透過度は 極めて瑟くなる・しかる後細胞膜は破わ顆粒は全く流出 し線毛上皮細胞の原型を止邓なくなる・かつる過程に要 する経過時間は多くのものは大体 15 分〜25 分であつて 平均 20 分前後に颃いて終末する.而し同一粘膜内の線 毛上皮にあってるアレルゲン刺战と同時に線毛運動は激 烈に六進し運動停止と同時に細胞は澄明となり短明閒内 に線毛の脱落, 細胞体の崩壊現象を呈してくるものもあ る.この現象の終了後な話子観察すれば脱落せる多くの 線毛が集積し，その一本一本の線毛は光沢を有し恰も活

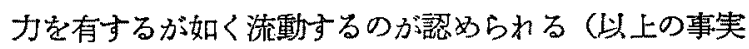
は映画に記録した)。

4）感作家鬼線毛上皮のアレルギー現象

成熟せる白色家鬼を20\% 卵白アルブミンにて感作し Arthus 反応陽性後生体のま〉副鼻腔を開放し粘膜を剔 出，生理的食湓水中に封入して観察するに，感作せるも の土線毛運動は正常のものに比し運動は軽度に減弱を見 せ，その運動頉度は正常のものより平均 $18 \%$ 減弱してい る. 又線毛の一部に脱落せる所を生じ全体的に線毛は粗 となつている・これに封入液を還流しながら抗原を作用 せしめると，作用直後より線毛運動は一時的に與舊状態 となり,1〜2分間激烈なる運動を経過した後急激汇減退 乙停止する.次いで原形質内に顆粒の増大, 水泡形成が 起り，線毛は脱落し，原形質の透過性が高まつてくるが， この時期より細胞は極度に膨化し，光の透過度が悪くな り，绦接せる細胞之押合うが如き感を呈し，細胞の膨化
は小皮縁に対して伸び，基整膜より遊離脱落して小皮緑 より崩壊現象を呈してくる。この現象は同一視野内の細 胞はほとんど㭙を同じくして起るが，1〜2 ケの細胞恃数 分遅机て発現する。モルッッの線毛上皮細胞に执いて も同様の反応を呈した (以上の事実は映画倍䐂した).

5) 感作家鬼副鼻腔に抗原注入

$2 \%$ 卵白アルブミンK括いて感作，Arthus 反応陽性 後の家象副鼻腔内に 注射器を以て0.1\%卵白アルプミン を注入し，1 時間後に副鼻腔を開放して一部粘膜を象離 し，これを $0.2 \%$ 葡萄楉加リンゲル氏液中に 封入して検 镜すると，細胞体は收宿現象を呈し，線毛運動は１分間 平均 260 回程度に減弱し線毛は小皮縁より多く脱落して 粗となっている・而しながら細胞体が基磷膜より遊離し ているものは認められなかつた・注入後 2 等間目に㔀離 剔出好る粘膜にあつては，細胞体は収縮して光の透過㡲 せ非常に悪くなつており，原形質内に顆粒が多く增加し ているのが認められた・全般的にみて線毛運動は殆んぞ 停止して赦り，中には微弱ながらす1 分間80〜140回䖽

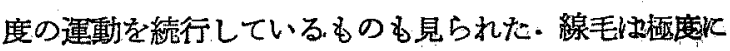
脱落現象を呈していたが細胞の膨化現象は琶められなか つた（以上の事実は映画に記録した）:

6) 感作家秃流抗動脈注射

$2 \%$ 卵白アルブミンにて感作し Arthus 区応陽性後の 家鬼に $1 \%$ 卵白アルブン $0.3 \mathrm{cc}$ を数回頸動脈に 注射し 注射終了後 1 蛙間目に副鼻腔を開放して粘膜を封入検鏡 せる所，細胞体山萎縮し 線毛運動は殆んど 停止してお り, 僅かに停止寸前のものが 2〜3認められるのみであ つた・線毛はその大部分が脱落し封入中に括いてをな拉。 次々と脱落して浮遊するのが見られる・細胞体は顆粒の 增大のためか，非常に光の透過度証悪く，原形質流動苋 見きわめる毫恃できなかつた（以上の事邦性映画化記録 (た).

6) ワコ・トニー状態下に和ける線毛運動

$1 \%$ 塩酸ピロカルビン $3 \mathrm{cc}$ を $100 \mathrm{cc}$ の リンゲル氏液 に混和し家乘腹壁皮下に点滴注射を行うと家鬼はワコト ニーの状態となる・斯くの如き操作で正常及び感作家鬼 をワゴトニーの状態にして細胞及び線毛運動を比較検討 した。

正常群の家鬼の洞粘膜上皮は細胞学的变化は認められ なからたが，線毛運動は 1 分間 280〜340回と中等度に 減弱を示していた。これに 1,000 倍アドレナルンを作用 せしめると1〜2分後より䠌毛運動は速かに克進し活發 な動きを見せ，その頻度る1 分間 420 回と正規の運動に 
復活し，正常粘膜の生理的食塩水封入㭙々全く同一飞な

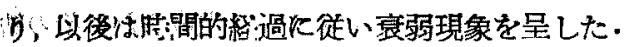

感作群口ゴトニーの線毛運動仙1 分間 240〜260回で 正常ワヨ゙トニーのものよりる幾分減弱して扣り線毛る粗 となつている。脱落せる線毛が媒質刀流れに乘つて流動 しているの住見られた：1,000倍アドレナリンを作用せ しめると線毛運動は著明な元進を見せ，活とんど正常近 く迄運動住回復した.

無感作ワゴトニー家鬼の線毛上皮細胞に $0.5 \%$ 卵白ア ルダミン刺战を加えても線毛運動及び細胞体に变化は諮 められず，生理的食塩水封入䐛とほ心同一なる衰弱現象 を呈した炕すぎないが，感作ワゴトニー状態の粘膜にあ

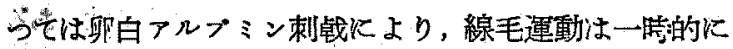

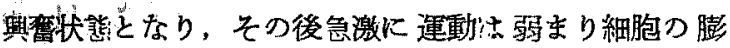
化，線毛脱落，崩壊現象を呈し細胞は基稳膜より遊離す る. この反応中正常感作家鬼のものに比較して極めて迅 速に且つ強く発現する（以上の事実は映画に記録した）。

8) 副腎剔出家鬼線毛絓胞火対する薬物及び アレルゲン刺敦

非感作にて副腎を剔出さるるのと副腎剔出後感作を施 した二群の家鬼において実験を行つた・

第3 图副筒剔出家鬼線毛紐胞に対する薬物制戟

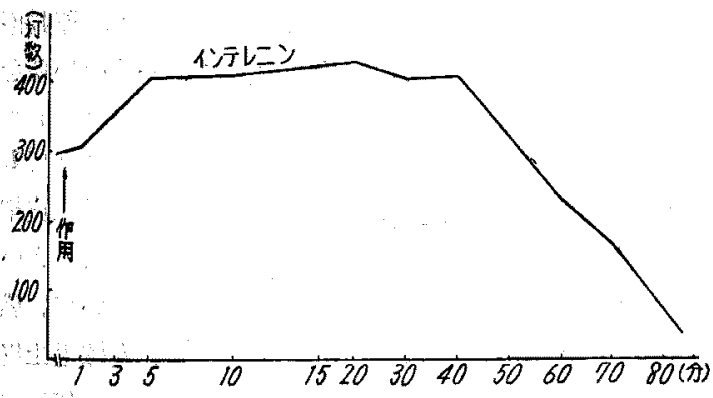

非感作群にあっては線毛運動は中等度に減弱し細胞体

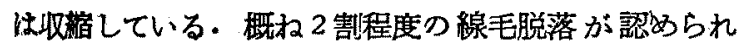
る.これ副腎皮質ホルモンであるインテレニンを作用 せしめると線毛運動恬潑に復元し，封入陆運動熲度が 290 回程度つ马のが作用後 5 分後には 410 回となり㟻㭙

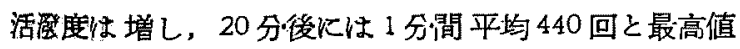
を示し 30 分後化至つてようやく衰弱の現象を現わし， 40 万出後上りは急激に減退し, 線毛運動の頻度方湗入㭙: の半数以下となるつけ. 70 分をを経過した後である。

感作副腎剔出せるもの>粘膜上皮は運動は極めて微弱 であり。その頻痛は1 1 分間 200 回〜210 回であり大半は 䠌毛の脱落が起り粗となつている. 細胞体の収緛む強く
光の透過度は極めて悪い.これにインテレニンを作用せ しめると大体非感作群とほら゙似た現象が起つた・インテ レンシの代りに抗原を作用せしめると線毛運動は一睹:穴 進した後 1 分間以内に㙋動を停止し細胞体刀膨化，線毛 脱落，基礎膜よりの遊殿，崩壊現象等が短時間の内に発 現しホ（以上の事実は映画に記録した）。

9）甲状湶切除家鬼の線毛細胞に対する蒋物 及びアレルゲン剌战

非感作甲状腺切除群と感作甲状腺切除家鬼の二群に就

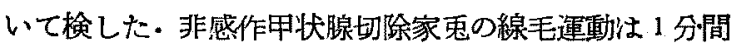
360 回と軽度の減弱を示し, 又線毛の脱落も余り認めら れず，細胞体つ収緛も又認められなかつた・これに甲状 腺ホルモンであるチラーデンを作用せしめると作用後 2

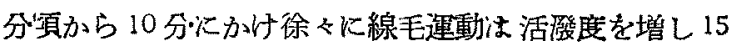
分にて全く正常のものと変らない状態となる.このよう な状態は約 50 分間持続し，封入㭙と同樣な線毛運動の 状態となるつは作用後70 分をを経過してからであるが， これ以後は逐次減退し 2 跀洞に和いて全く停止した。

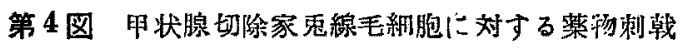

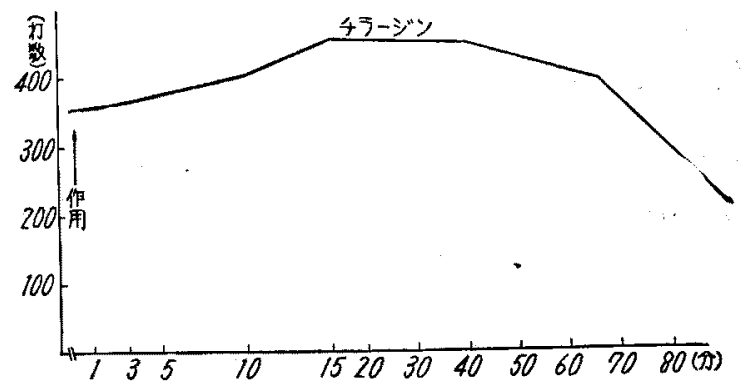

感作甲状腺切除家乘群に抢ける線毛運動は1 分間平均 320 回程度に減弱を示し線毛も相当底に脱落していた。 而しながら細胞体の収縮現象は認められず又細胞の光の 透過度す良好である・これにチラーデンを作用せしむる と，非感作群つ場合とほ心゙同様な現像を現わした・アレ ヘダンを作用せしめれば前記同递運動停止 $\rightarrow$ 膨化 $\rightarrow$ 線毛 脱落 $\rightarrow$ 基楚膜遊離 $\rightarrow$ 崩髙つ現象を呈した（以上つ事契は 眏画に記録した).

10）線毛細胞に対する菌液つ作用

人鼻腔より寒天培地に培養せる菌を 1 白金耳取出し, これを10cc の生理的食塭水溶解をしめて菌液を作 り，これによる皮内反応及び沈降反応陽性なる患者つ線 毛細胞に，同種の菌液を作用せしめると，整晊にして線 毛運動外與窝状態を示すことなく徐々に緩慢となり停止 する. 更に数分の後には線毛の配列が乱れ始め，所々脱 
落するものが現われ，細胞体には顆䗑が増加し光の透過 度性鏠くなり罙胞形成を起し膨化し，次いで崩填現象を 呈してくろ. 菌液作用後から崩填气の過程において, 細 胞体には収繀の現象は見られなかつた・上記現象を起す 過程性約 40〜50 分内外である.而して卵白の如き急速

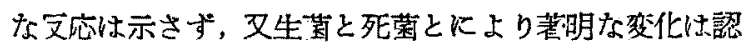
められなかった。

\section{IV 䑶括並に考按}

近年アレルギ、学が勃與するに及んで医学の各分野に 亘つて從来原因不明とされた疾患にアレルギー学的立場 よりこれを解明せんとする研究が行なわれる様になつ

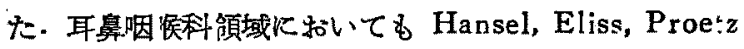
等つ学者がフレルギー学的立場より慢性副鼻腙炎を解明

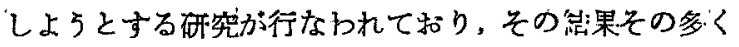
がアレルギー機序によつて発生することが喼められた。

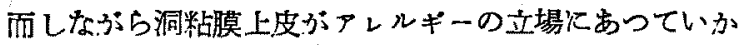
なる䈍度をとるものであるうかと云うことについては末 た研焭がなされていなからた、人体に和いて直接アレル ギー反応を起させることは困難であるから，私は洞粘膜 の線毛上皮細胞のアレルギー反店を実稀的に位相美顕微 鏡下に観察せんと試みた訳である。

かつて Harrison は動ているゾウり虫を乘の血清中 に封入し，あらかじめ antigen に対しては自由に運動 する動物の線毛を allergen に曝すと，運動次弱くなり 形を变光休止するに至ると述へている. 又筆”畔胞つアレ ルギー反応つ研究には武田肉腫によるものぶある.1955

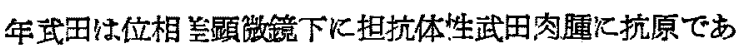
る卵白を作用させると，細胞体は㴼少し細胞顆粒は増加 するが，次で細胞本は膨化し原形哥は澄明となり細胞顆 粒は䅭周に集合し核自身は長くその姿を現わさず，長时 間後冗細胞は融合融解儿移行する.がる变化は抗体を 含も細胞に抗原が波及して起る自然あるい怔常のアレ ルギー反応であると述へててる、そこで私は前記の如く 人上顎洞粘膜上皮々家㥦の粘膜上皮にアレルギー反応を 起さしめた・次にこれ等つ実㫫結果を検討し考察を加え てみたい.

ヒスタミンは組織中広く分布して括り，これは抗原 抗体反応を助長し，及ヒスタ、ンとアセチールンリンは アレルギー反応つ際に生ずる有毒物質であるとされてい る.今，ヒスタ、ン及ぶアセチールコリンを線毛上皮に

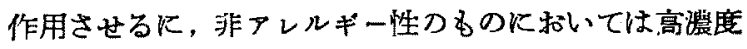
以外は単なる運㲜六進を見たつみであつたが、アレルギ 一性つもので稀薄なむのでも明らかにアレルギー反応
と酷似した現象学起した・これはナレルギー現象の場合 にはヒスタミンやアセチールラリンが生成され，その綃 果起る反応であることを暗示するるのである・文これ等

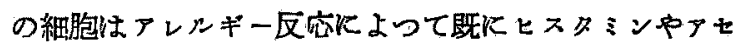
チールュリンを多少保有していることが推定できる。細 胞炕っては実に鋭敏に作用反応を呈するるのがあった が，反対に高浱度則においてる鈍感沉反応を現わするの ああつた・これはその細胞体に库生蓄積された七スタミ ン量あるいはアせチールコリンの量つ多宾基ずくの であると思玑る・而し反応を呈する濃度を比較すると ヒスタミンよりるブチールコリンの方が，占り低猪度 で反灾が強く現われる.これは両者の細胞内に和ける量 的関係より，むしろ細胞体に括ける薬物の感受性，むを いは親和性こ基ずくものであろ5と解㭱される・以上か

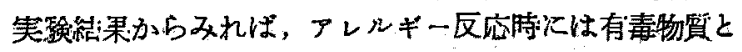
してヒスタミンとアセチールコทンが生成され，そのた

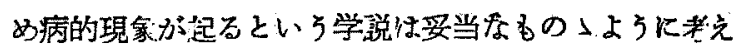
られる。

慢性副鼻腟炎患者つアレルゲンが判明せるすのつ洞粘 膜線毛上皮細胞に，そのアレルぶンを作用せしめて，こ れがアレルギー反応を呈するや否やを検討してみたとし ろ，抗体を有するるの小線毛上皮は抗原の刺㦸炕よって 明らか火細胞の一期的與鹪状熊, 細胞体萎縮, 運動停 止，線毛脱落，膨化崩堎と短時間つ内に，一連の現象を 発見した・このことは異種の抗原であるとか㚣はアレル ギー因子を有しないものに高濃度のものを作用させてる 变化を認かなからた事事からして, 明らかに線毛上皮細 胞に和ける抗原抗体反度を呈したすの子解釈してすよい

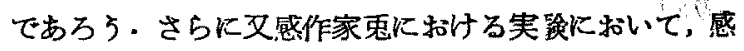
作せるるのと同一抗原の稀釈液を作用させ，人線毛上皮 と同康つ反灾が起つたつを見たが，これに反して無感作 群化特いてはいかなる反店る呈しなかつた・このことは 人楾毛上皮にる抗原抗体必応が起り得ることの証左とな すК足るるのである.

家鬼の組織片に括いては膨化現象と同的:沉線毛細胞生

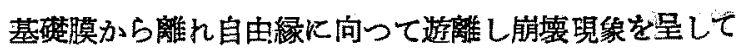
いるが，これはナレルゲン刺钱よつて細胞ぶ膨化するた ぬ体漬を增し，細胞つ密集群の内にあって相互の圧迫に よるため，基等膜より離几自由緑に伸びるむのが完られ

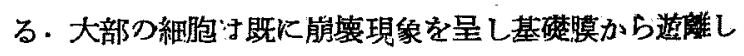

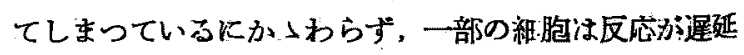
し，䏢化が遅れたものでは，相互の医迫が無いたかか，

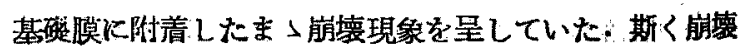




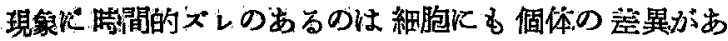
り㚣，抗原の作用が平等て行われないためであるら。

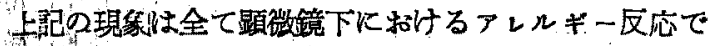
あって、実祭に生体内扎いては同様なる反応が起るすの である5かと考充に達し，家鬼副鼻腔をアレルギー反応

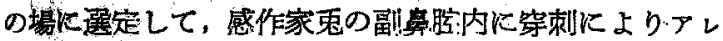
えバンを滴下し一定措明の後にこれを検したが，生体内 に和いては影微鏡下におけるが如き顕者な反灾は出現し なからた. しかし, Hilding 奴び Ballenger の云らが

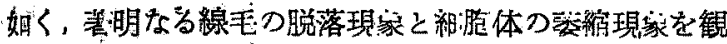
察することはできた。この笑淠から感作せる粘膜に抗原

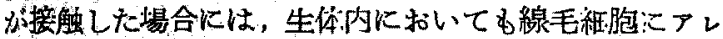
ヘギ，反庁は起るが，顕微鏡下とはや小趣が黑なり線毛 細胞火軽度つ形熊学的変性を起すのみである。

前記の生体内に和ける䄄胞の形態学的变性恰感作家鬼 にフレルゲンを钼動派注射した祭にる起り得る・かつる

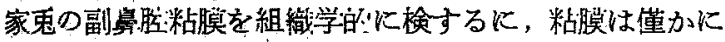
浮腫状呈し線毛袖胞は軽度に膨化し，線毛は一部说落 して洞内に少量つ線䊒素㴍の分"必物が存在するのが見ら れるのみで，前記の顕微鏡下の所觉の如き顕茊な变化は なからた. 従って線毛つ脱落は生体内では余り高度に起

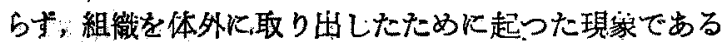
と覞做すべきである：従つて斯くの如くアレルギー反応 を起した粘膜は刺战に対して抵抗力が非常に減弱してい

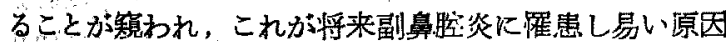
となり得ることが推測できる・血液を介して抗原が洞粘 橂化作用寸ることは食期性フレルギ一の場合に条件が酷 似しているから人間に和いても，体内で斯くの如き反店 が起り得ることが考充られよう。

自律神絟機能はアレルギーにおいてて抗体應生及び動員 を与兄る影響を有している．即ちアレルギー菜因万至素 質の本態火は自律神綴緊張状態の異常ジ大さな役割をな しているもので㐫る・江良は夷験的アレルギーにおいて

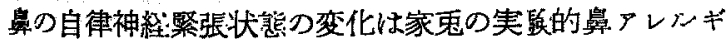
一を堌悪させると述へている・1931 年 Lucas は線毛運 動は神粉:支配によつて大きな制約を受けると述べたが，

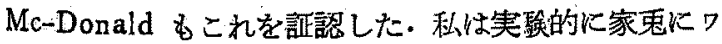
コトーーを誘発せしめワコトニー状態における線毛運 動やワゴトニーとアレルギー因子とを共有せる場合つ上 皮の变化を観祭した成績では，ワゴトニー状態下の線毛 運動恃明らか減弱を示し，そしてこれが感作されたる すのにあつてはさらに機能的隇退が強く、アレルギー反 灾も正常感作家象のものK比较して極めて迅速に且つ強
く現われた・この実駼からして、ワコトニーの者ぶ副舅

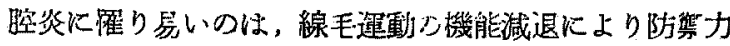
が減弱し，他方アレルギー反応が高度に起り得るためて あると解すべきである。

1955 年 Hussarek は副篦皮筫の疾病はアレルギー性

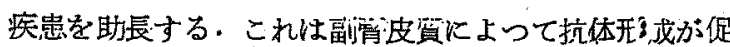
されないならば，超過敏症となり免疫反応性分散される と述べている．Messer-klinger は動物実䠑火より副骨

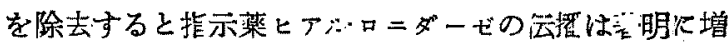

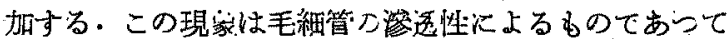

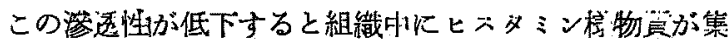
䅡しそこに可応は強く起ると述べている，私は実㩆的に 副骨を剔出したものと，甲状腺を切除したるのとにこい て検したが，いずれの場合に括いてる線毛細胞は機能減 退しアアレルギー反応が正常のものよりも強く発現する ことを認めた：而し副骨を欠くももの、方が後者に此

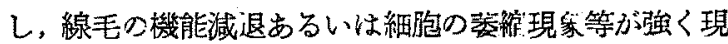
われて拈り，又アレルギー反㐫も前者の力゙が強く発現す る・これによって副奥腔は副管皮資ホルモンによる影響 が非常に大であることが矮知される。

Forman は與アレルギーは，甲状肪機能障得とは一定 の関你はないと述へて招るが，Proetzは甲状腺の機能 障碍は鼻の細菌感染や莮アレルギーつ発現炕好都合に働 く傾向があると云つている.甲状腺を切除したものでは 線毛細胞は軽度刀機能減退を認めるのみで，形等学的変 性迄もきたさないことよりして，甲状腺は副舞腔粘膜の

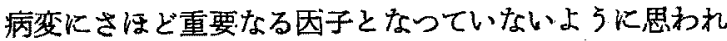

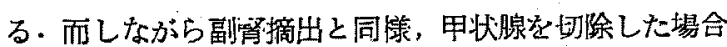
でる線毛上皮刀機能减退せるすのに各なの水汹モン郕つ 刺㦸を与える事炕より，その機能が全く正常に復活した ことから若えれば，各ホルモンは線毛細胞つ生理的機能 を保維する上K必須つるのであることがわかる・しかし これ等つ内分必腺は自律神経緊张保維阔与することが 大であるから，そつホルモンが直接線毛細胞に衝くの か, あるいは自律神絟に先づ作用してしかる愽腺毛細狍 に影響を及ぼすのか怯明らかではない，私は臨床的に慢

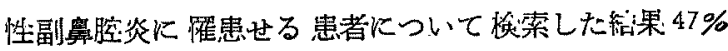

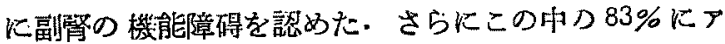
レルギー性つるのがあり，副筒機能とアレルギーとは密 接なる関係を有していることを推定していたが，この実 験結果はこれを襄書きするに十分であ万う。

慢性副鼻腔炎の埸合に細菌性アレルギーが重要な役目 を持つことは近時潮く明らかになってきた・細藏性つレ 
ルギーが起つて赫るとすれば，菌液によってる線毛上皮

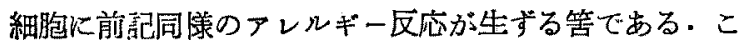
んな考え方から実鈋を行った所, 菌液によってる他のア レルゲンと同様な反応が起つた。この場合においては生 菌，死菌による差は反応飞認められなからたが，この反 応は卵白アルブミン等による反応より約 2 倍蚉つ長時間 を要した。これは細菌体やその分泌物が抗原となること を示するのではあるが，菌体の蛋白質は抗原性が弱いと 見えアアレルギー反応の発現時間，発現程度が著しく遅 れ且つ低調である。

以上の如〈私は人䠌毛上皮劣るい性家身の䂒膜上皮に 就て線毛上皮細胞の抗原抗体反応を観祭したが，この成 結から観れば慢性副鼻腔炎の成立要素中には、アレルギ 一反応は見逃すことのできない重要な現象でむることが 推測できる。

\section{$\mathbf{V}$ 結 語}

私は人並に家鬼の線毛上皮細胞にアレルギ一反分を生 ぜしめ位相竞顕微鏡下に観察し次のような結果を得た。

1) 人線毛上皮細胞は七スタミン刺㦸化対し, 非 ルギー性のものは10 倍以下の 浱度で崩壊現象を呈する が，それ以上に扮いては単に線毛運動は六進するのみ である.アレルギー性では2.000 倍以下の浱度で細胞 体の収縮, 连動允進, 停止, 線毛脱落崩壊現象を呈与 る、アセチールコリン刺战に対しては非アレルギー性は 1,000 倍头下で崩壤し，アレルギー性ては 5,000 倍以下 で崩壊現象を呈する・ヒスタミシ並にア七チールコリン 刺战による崩壊現象はアレルギー反応に酷似し，アレル ギー反応の場合に前記毒物が偟生せられることが窺知さ わる。

2)アンルギ一欧子を有する人副鼻凌線毛上皮は同一 抗原の作用により細胞体収縮, 運動》一時的六進, 顆粒 の增大，線毛脱落，膨化，崩壞の現象を起し，町白アル ブミンで感作した家鬼の副舅腔粘膜に同一抗原を作用せ しむれば，人線毛細胞と同様な变化を起し，基碐膜より 遊離し崩壊した。

3) 感作家秉副鼻膣に 抗原注入を行えば線毛運動つ中 等度減弱, 細胞収縮, 線毛脱落等つ变化が起つたが, 顕 微鏡下で見たような，顕著なアレルギー反応を認め得な かった・従って生体内においては顕微鏡下のような高度 なアレルギー変化は起り得ないと言える.

4）感作家鬼に抗原動脈注射を施したものでは線毛運 動怡んど停止し線毛の高度脱落，細胞の类縮現象を認 めた。斯かる現像ば食期性アレルギーの場合に人間に和 ててる発見し得ることが憶測せられ，これが将来副蕃胵 炎発生に大きな器義を有するすのと考学られた。

5) ワゴトニー状態下の 線毛運動は中等度汇減弱を示 すが，これにアドレナリンを作用せしめると線毛運動は 正常に復活する。この状態のものにアレルゲンを作用せ しめるとアレルギー反応は正常感作家臣のものよりも区 応忏迅速且つ強く発晲する。
6）副督を剔出せるもの今線毛運動は中等度汇減弱し 且つ2割程度に線毛刀脱落があり細胞体は萎縮している がインテレニンを作用せしわると線毛運動は正常に復活 する。副督剔出後感作せるすのでは更に線毛運動は微弱 であり脱落る高度である。これにアレルゲンを作用せし めると短時間内に高度のア゙レルギー反応を呈する。

7）甲状瑔を切除せる線毛運動は軽度の減鸿を 示すが 線毛脱落及び細胞つ收縓は認められないここれにヂラー デンを作用せしむれば線毛運動记正常に復活する。感作 せるるのむ線毛運動は軽度汇減弱を示すの及であるが， これにアレルゲン刺战を加えればよくアレルギー反応を 呈する.しかしこの場合の反応は副腎摘出の場合に比し 概して軽度である。

8）細菌沈降反応陽性なるるの〉洞粘膜上皮火同種菌 液を作用せしめると，線毛細胞には同様アレルデー反応 が起る・而し反応発現時;間は他の抗原に比し長く，且低 調である。

\section{主 要 文 献}

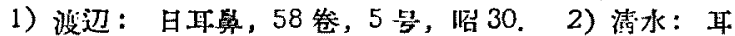

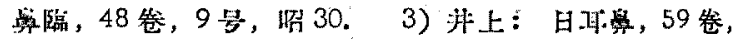

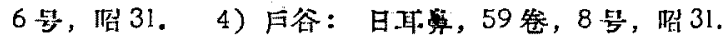
5) 湯浅: 細胞学, 同文館, 1942, 6) 武国: 臨林了

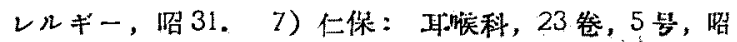
26. 8) 矢野：アレルギー, 4 卷, 2 둑, 炤 30. 2)

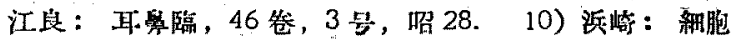

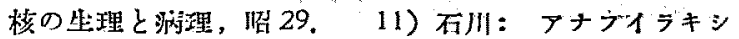

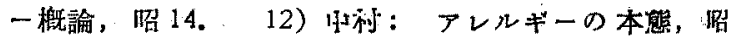

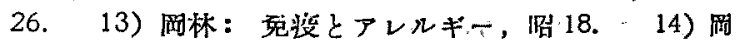

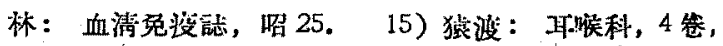

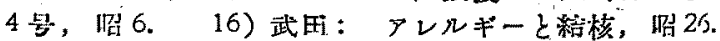
17) 畔柳: 臨林アレルキ二, 骝 31. 18) Rose: Anat. Rec. 409; 104, 1949." 19) Hansel: Clinical Aller. gy, 1953. 20) Proetz: Applied physio.of the nose, 1946. 21) Ballenger: Ann. ot. etc. 58;351, 1949. 22) Hilding: Ann. ot. etc. 41 ; $52,1932$. 23) Hilding: Ann. ot. etc. 53; 35, 1944. 24) Hilding: Ann. ot. etc. 52 ; 5, 1943. 25) Lucas: j. morphol. 53 ; 243, 1932. 26) Gray: Experimental Cytology 1931. 27) Messerklinger: Zschr. Laryng. 3; 1, 1956. 28) Messerklingr: Zschr. Larng. $475 ; 165,1954 . \quad 29)$ Messerklinger: Zschr. Laryng. $344 ; 169,1955$.

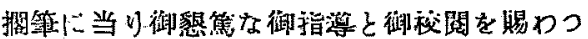

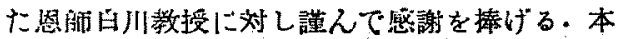

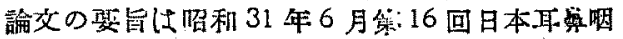

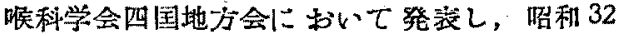

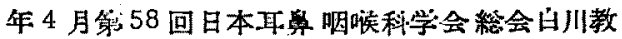
授缩題辣告の一部として発萃，同暗に $16 \mathrm{~mm}$

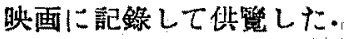

（原稿到着 $=$ 沿和 33.9 .6 日一急載） 
松 本 論 交 附図（第 II 編）（1）

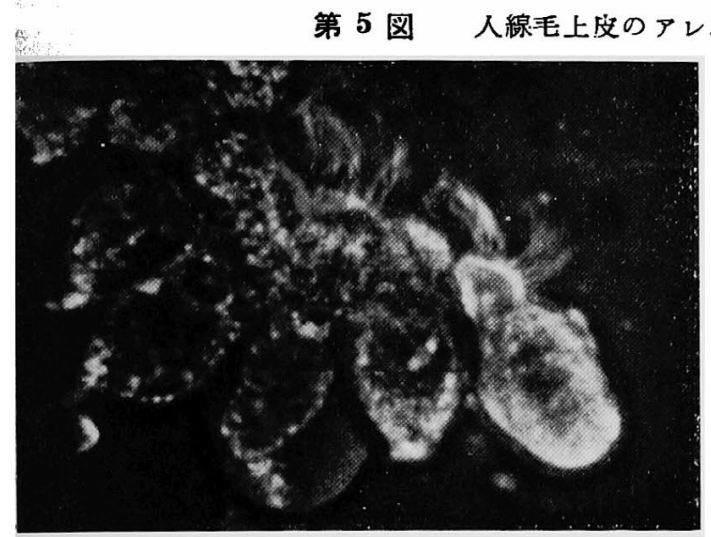

人副鼻腔腺毛上皮・アレルゲン制戟前

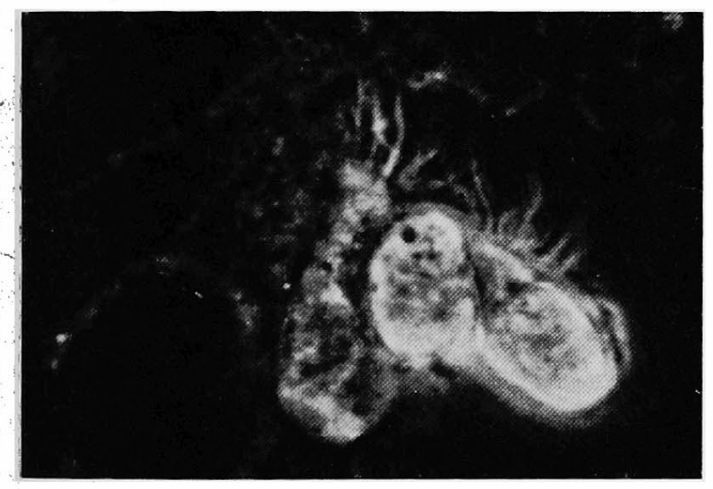

剌戨後(10 分)

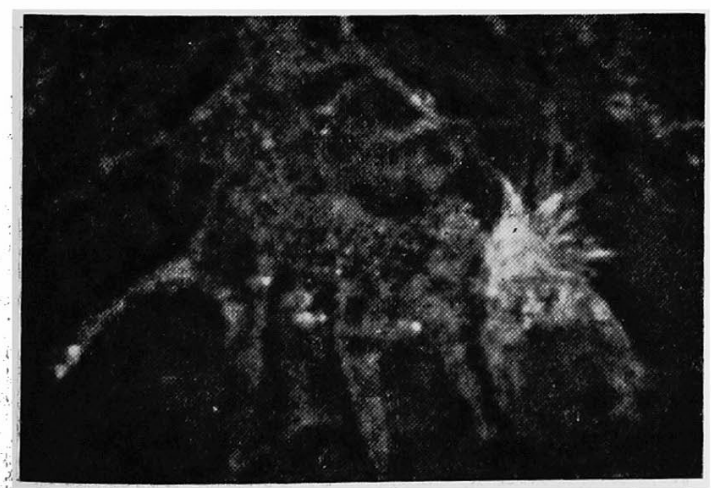

制 戟 . 後 (20 分)

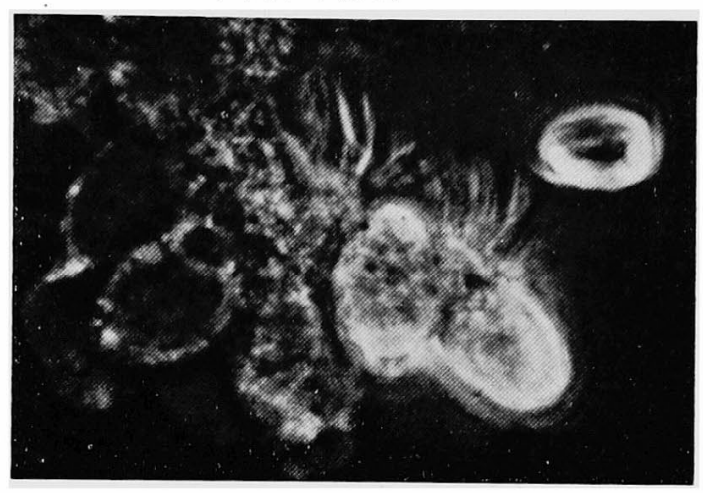

アレルゲン刺戟後（5 分）

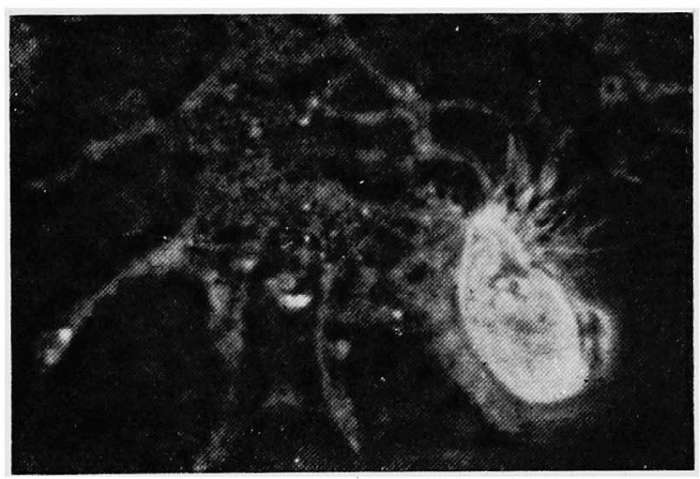

哵 㦸 後 (15 分)

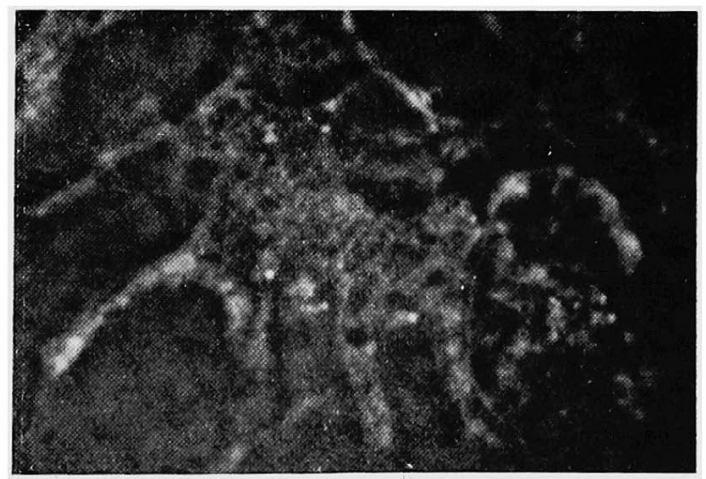

欶韩後(25 分) 


\section{松 本 論 交 附 図（第I編）（II）}

第 6 図感作家鬼副悬㓐線毛上皮のアレルギー反応（16 $\mathrm{mm}$ 映画占り枟写）

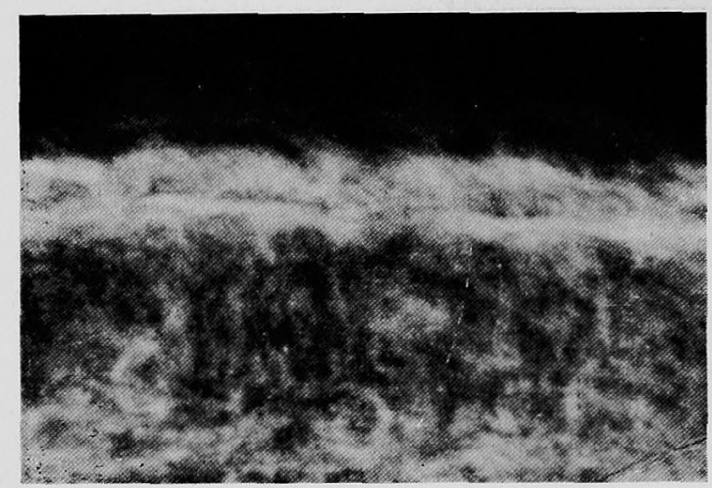

感作家鬼副實腔線毛上皮 (作用前)

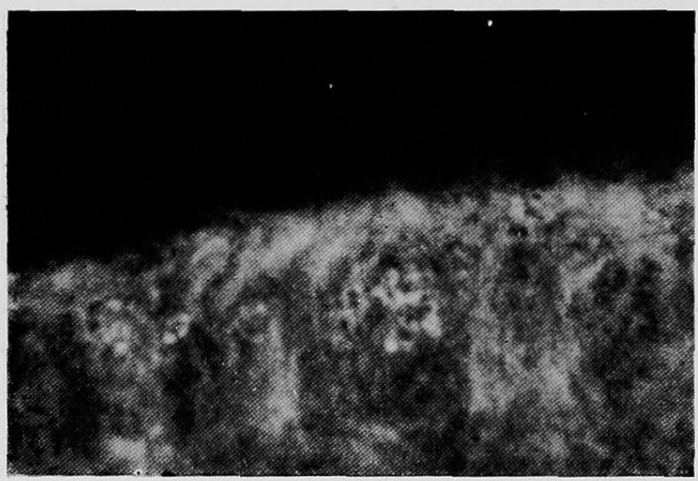

刺战後 (5 分)

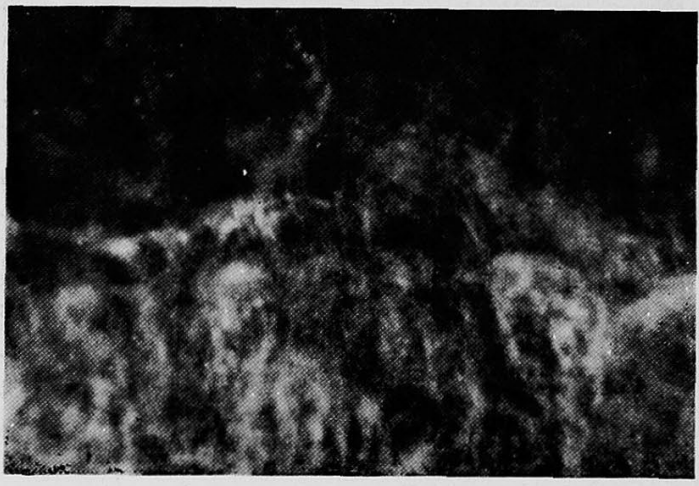

刺战後 (15 分)

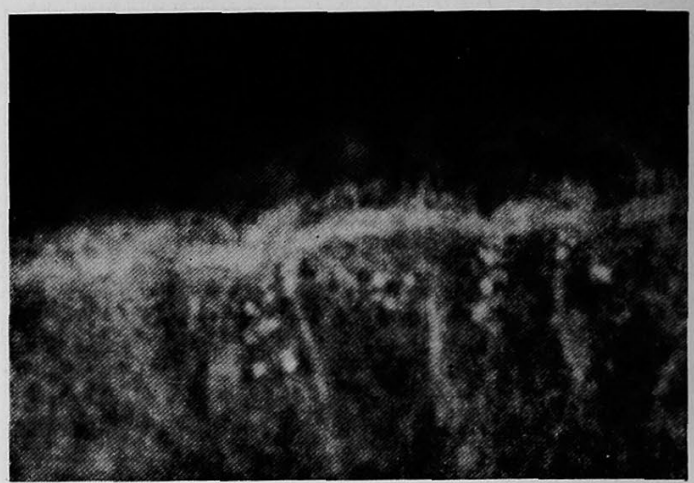

アレルゲン刺戟後（3分）

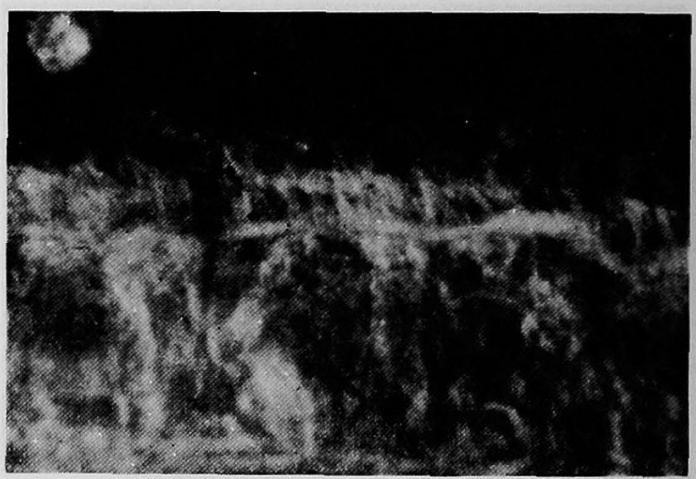

刺戟後(10 分)

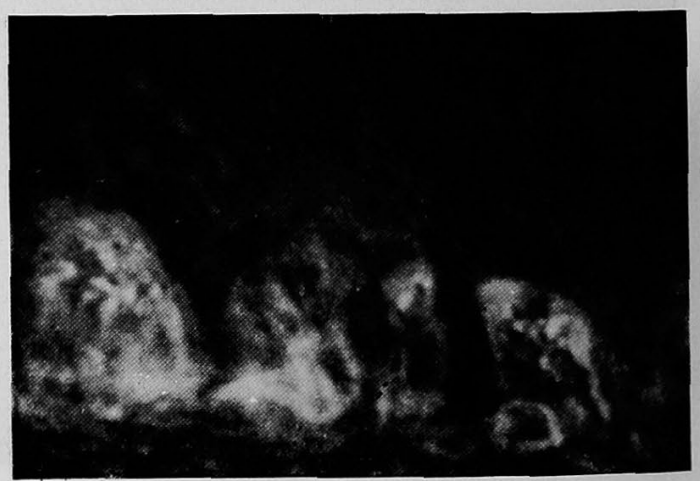

刺战後(20 分) 


\section{烃 本 論 文 附 図（第 II 編）（囵）}

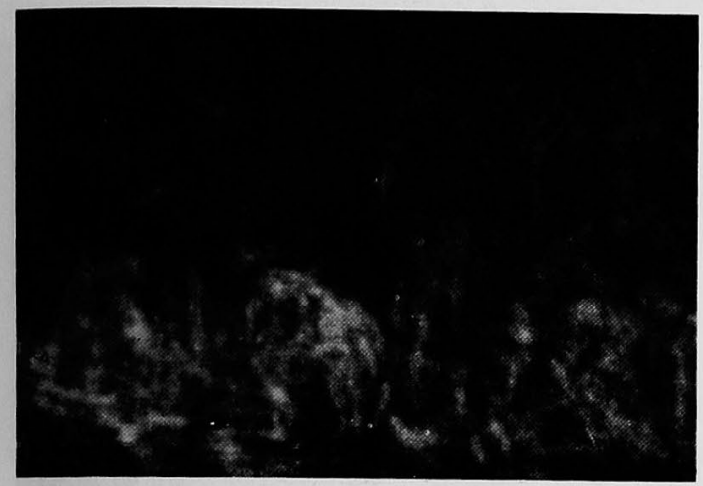

制戟後(25 分)

第 7 図 感作家鬼副悬些抗原注入後 1 時間目 のもの, 線毛は粗となる

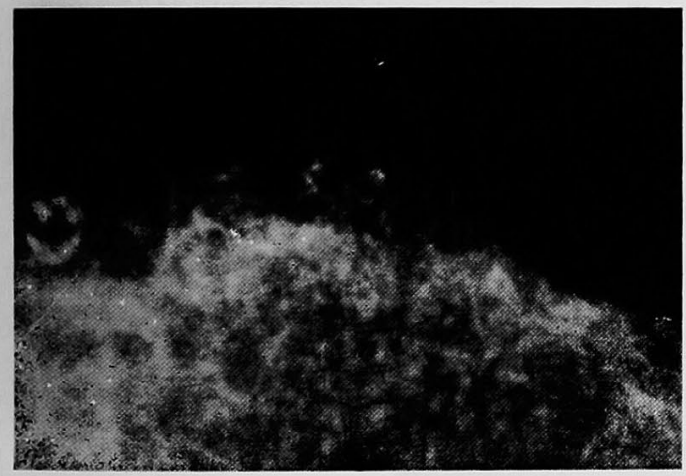

第9図感作家鬼抗原動脈注射, 細胞体苳綰, 線毛脫落

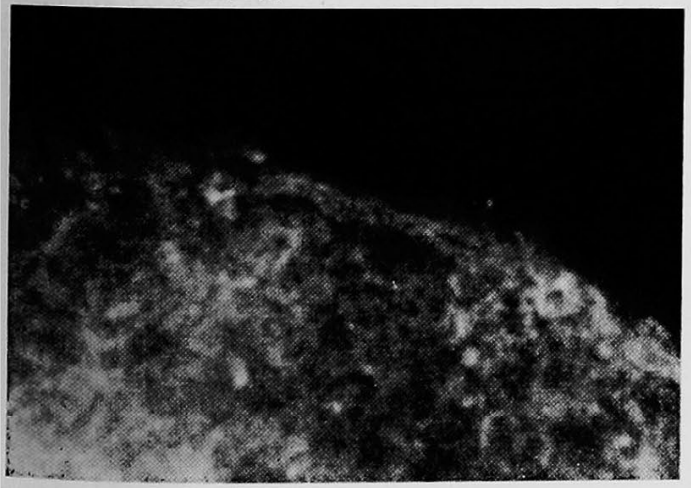

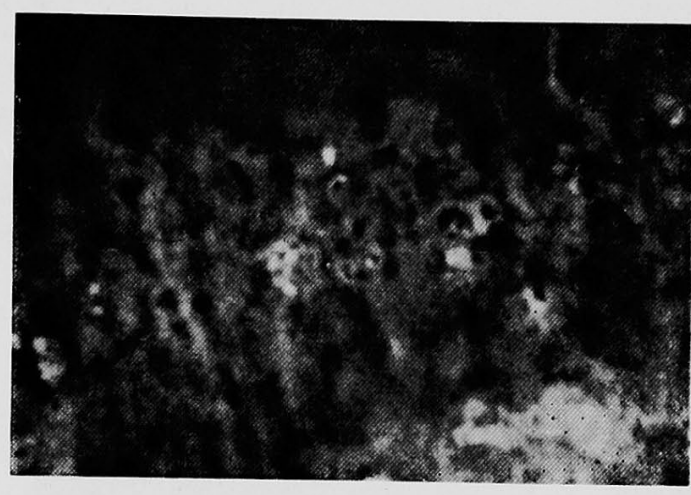

制战後 (30 分)

第 8 図感作家鬼副鼻腔抗原注入後 2 路間目 のもの, 紐胞蒌縮, 線毛脫落

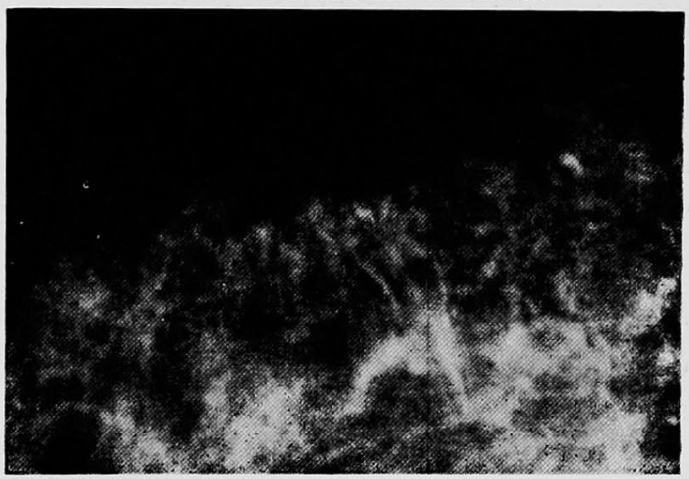

第 10 図無感作ワゴトニー状㮩の線毛上皮

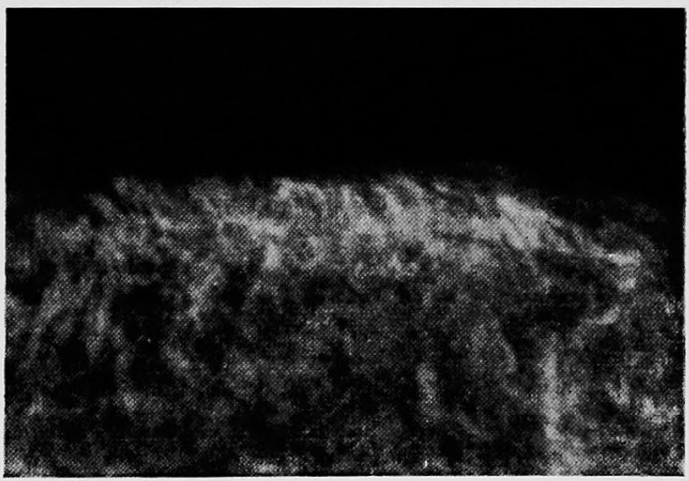




\section{松 本 論 文 附 図（第II編）（IV）}

第 11 図 感作ワゴトニー状態の線毛上皮

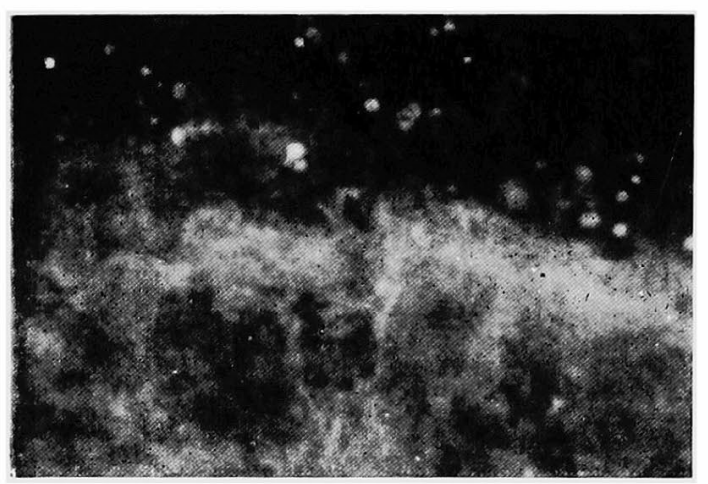

第 12 図副肾剔出感作家鬼の線毛上皮 級胞体篓縮, 線毛は粗となる

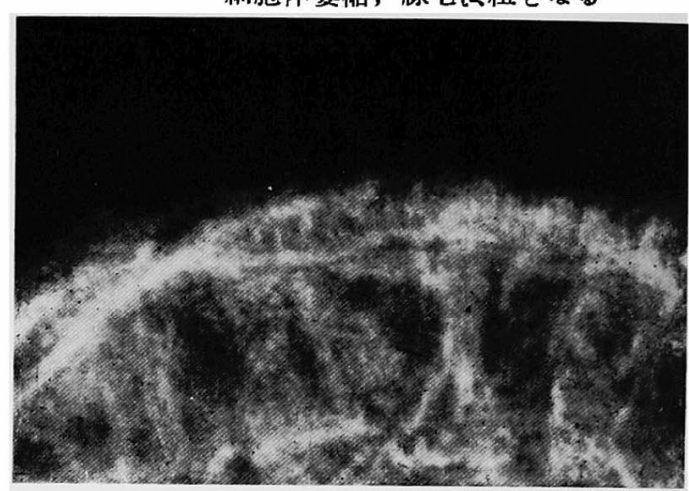

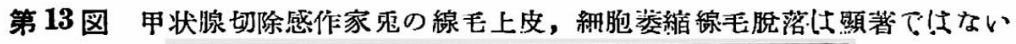

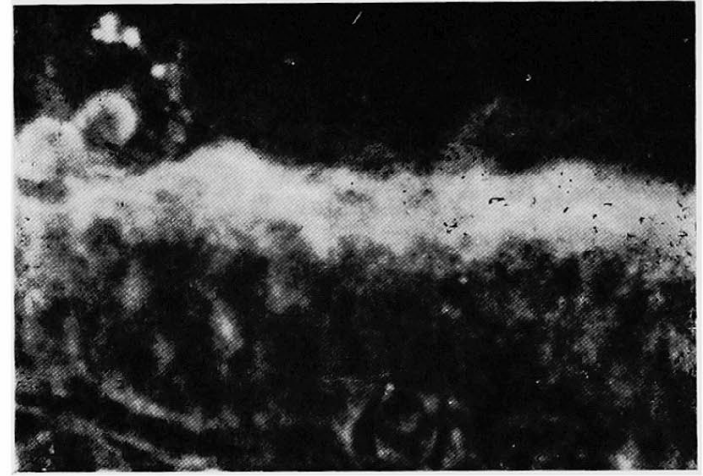

